\title{
Kisspeptin Signaling Is Required for Peripheral But Not Central Stimulation of Gonadotropin-Releasing Hormone Neurons by NMDA
}

\author{
Xavier d'Anglemont de Tassigny, ${ }^{1}$ Karen J. Ackroyd, ${ }^{1}$ Emmanouella E. Chatzidaki, ${ }^{2}$ and William H. Colledge ${ }^{1}$ \\ ${ }^{1}$ Reproductive Physiology Group, Department of Physiology, Development, and Neuroscience, University of Cambridge, Cambridge, CB2 3EG, United \\ Kingdom, and ²Department LabMed, Division for Metabolic Diseases, Karolinska Institutet, Novum, 14186 Stockholm, Sweden
}

\begin{abstract}
NMDA and kisspeptins can stimulate gonadotropin-releasing hormone $(\mathrm{GnRH})$ release after peripheral or central administration in mice. To determine whether these agonists act independently or through a common pathway, we have examined their ability to stimulate $\mathrm{GnRH} /$ luteinizing hormone (LH) release after peripheral or central administration in Kiss1- or Gpr54 (Kiss1r)-null mutant mice. Peripheral injection of NMDA failed to stimulate GnRH/LH release in prepubertal or gonadally intact mutant male mice. Dual-labeling experiments indicated a direct activation of Kiss1-expressing neurons in the arcuate nucleus. In contrast, central injection of NMDA into the lateral ventricle increased plasma LH levels in both Kiss 1 and Gpr54 mutant male mice similar to the responses in wild-type mice. Central injection of NMDA stimulated c-Fos expression throughout the hypothalamus but not in GnRH neurons, suggesting an action at the nerve terminals only. In contrast, kisspeptin-10 stimulated LH release after both central and peripheral injection but induced c-Fos expression in GnRH neurons only after central administration. Finally, central injection of NMDA induces c-Fos expression in catecholamine- and nitric oxide-producing neurons in the hypothalamus of mutant mice, indicating a possible kisspeptin-independent $\mathrm{GnRH} / \mathrm{LH}$ release by NMDA through activation of these neurons. Thus, NMDA may act at both GnRH cell bodies (kisspeptin-independent) and nerve terminals (kisspeptin-dependent) in a dual way to participate in the $\mathrm{GnRH} / \mathrm{LH}$ secretion in the male mouse.
\end{abstract}

\section{Introduction}

The development of normal reproductive function in mammals requires pulsatile secretion of gonadotropin-releasing hormone (GnRH) from the hypothalamus. GnRH stimulates the release of the pituitary gonadotropins [luteinizing hormone (LH) and follicle-stimulating hormone] that regulate normal gonadal activity. GnRH release is influenced by several factors, including sex steroids, growth factors, neurotransmitters, and neuropeptides (Herbison, 2006). One of the most potent stimulators of GnRH release is the kisspeptins (Kp), encoded by the Kiss 1 gene. Kisspeptins are a family of overlapping peptides ranging from 54 aa (Kp54, also known as metastin) to 10 aa (Kp10) in length (Kotani et al., 2001; Muir et al., 2001; Ohtaki et al., 2001). Kisspeptins mediate their biological activities through the G-protein-coupled receptor GPR54 (also known as KISS1R), which is expressed by GnRH neurons (Irwig et al., 2004; Messager et al., 2005; Navarro et al., 2005). The majority of GnRH neurons

Received Nov. 5, 2009; revised April 9, 2010; accepted May 10, 2010.

This research was supported by Biotechnology and Biological Sciences Research Council Grant BB/F01936X/1 and the Ford Physiology Fund. We thank Prof. Allan Herbison for his comments on this manuscript and Cara Walters and Richard Carter for technical assistance in mouse genotyping. We are also grateful to members of the Experimental Psychology Department of the University of Cambridge for using the stereotaxic equipment and Prof. Anne Ferguson-Smith, Dr. Sacri Rodriguez-Ferron, and the Center for Trophoblast Research for the use of their microscope.

Correspondence should be addressed to Xavier d'Anglemont de Tassigny, Reproductive Physiology Group, Department of Physiology, Development, and Neuroscience, University of Cambridge, Cambridge, CB2 3EG, United Kingdom. E-mail:xd211@cam.ac.uk.

DOI:10.1523/JNEUROSCI.5486-09.2010

Copyright $\odot 2010$ the authors $\quad 0270-6474 / 10 / 308581-10 \$ 15.00 / 0$ respond electrophysiologically to Kp10 (Han et al., 2005) as well as show c-Fos expression after intracerebral injection of Kp52 (Irwig et al., 2004). Both peripheral and central injection of Kp induce a robust and sustained $\mathrm{GnRH} / \mathrm{LH}$ release in most species (Gottsch et al., 2004; Navarro et al., 2004; Dhillo et al., 2005; Messager et al., 2005; Navarro et al., 2005; Shahab et al., 2005). Mice with a targeted disruption of either Gpr54 (Funes et al., 2003; Seminara et al., 2003; Dungan et al., 2007; Kauffman et al., 2007; Lapatto et al., 2007) or Kiss1 (d'Anglemont de Tassigny et al., 2007b; Lapatto et al., 2007) are sterile with absence of sexual maturation at puberty as a result of defective GnRH release.

Another important stimulator of GnRH release is the neurotransmitter glutamate (Olney et al., 1976; Ondo et al., 1976) with an increase in glutaminergic signaling in the hypothalamus at puberty (Parent et al., 2005). The NMDA receptor is a glutamate receptor subtype that is required for $\mathrm{GnRH}$ secretion in rodents (Bourguignon et al., 1989) and primates (Plant et al., 1989; Claypool et al., 2000). Although GnRH neurons express NMDA receptor subunit 1 mRNA (Ottem et al., 2002), there is little evidence of a direct action of NMDA on GnRH neurons, consistent with the absence of c-Fos induction in GnRH cells after NMDA treatment (Saitoh et al., 1991; Lee et al., 1993). These data suggest that NMDA may not stimulate GnRH neurons directly but that its actions may be mediated through other pathways. We hypothesized that kisspeptin signaling through GPR54 may convey the NMDA signal to GnRH neurons. To test this hypothesis, we have undertaken a series of whole-animal investigations using Kiss1- and Gpr54-null mice. First, we examined whether Kp sig- 
naling is essential for NMDA-induced GnRH/LH release after peripheral or central injection. Second, we evaluated the possible action of NMDA on kisspeptin neurons in the arcuate nucleus (Arc). Third, we investigated the effect of central injection of NMDA on catecholamine- and nitric oxide (NO)-producing hypothalamic neurons to provide additional information on the kisspeptin-independent action of NMDA on LH release.

\section{Materials and Methods}

\section{Animals}

Experiments were undertaken on prepubertal (24-26 d old) or adult (2-3 months old) male 129S6/SvEv Gpr54-null (Seminara et al., 2003) and Kiss1-null (d'Anglemont de Tassigny et al., 2007b) mice and their wild-type siblings. Mice were housed under a $12 \mathrm{~h}$ light/dark schedule (lights on at 6:30 A.M.) with ad libitum access to food and water. Genotypes were determined by PCR as reported previously (Seminara et al., 2003; d'Anglemont de Tassigny et al., 2007b). All animal procedures were performed under authority of a United Kingdom Home Office Project License and were approved by the Cambridge Animal Ethics Committee.

\section{Drugs and antibodies}

Kp10 [human Metastin (45-54) amide; M-2816] and NMDA (M-3262) were purchased from Sigma-Aldrich. Rabbit polyclonal anti-GnRH antibody was a generous gift from Prof. G. Tramu (University of Bordeaux 1, Talence, France) (Beauvillain and Tramu, 1980) provided by Dr V. Prevot (Inserm Unit 837, Lille, France). Rabbit polyclonal anti c-Fos (SC-52) was purchased from Santa Cruz Biotechnology and used on mouse tissue (Clarkson et al., 2008). Rabbit polyclonal anti-neuronal nitric oxide synthase (nNOS) (61-7000; Invitrogen) and anti-tyrosine hydroxylase (TH) (BA-152; Millipore Bioscience Research Reagents) were tested previously on mouse tissue (Horger et al., 1998; Page et al., 2009). Secondary goat anti-rabbit biotin-conjugated (BA-1000), anti-rabbit peroxidase-conjugated (PI-1000), and Vectastain ABC kit (PK-4000) were purchased from Vector Laboratories.

\section{Peripheral injection protocol}

Prepubertal mice. Four to six animals (24-26 d old) of each genotype (Kiss1-null, Gpr54-null, or wild-type) received a single intraperitoneal injection of $100 \mu \mathrm{l}$ of $2 \mathrm{mmol}$ of NMDA in PBS or PBS only. Mice were killed by $\mathrm{CO}_{2}$ exposure $10 \mathrm{~min}$ after injection. Blood was collected in a heparinized syringe from the inferior vena cava and centrifuged at $10,000 \times g$ for $10 \mathrm{~min}$ at $4^{\circ} \mathrm{C}$. The plasma supernatant samples were collected and stored at $-20^{\circ} \mathrm{C}$ until assayed.

Adult mice. Three to nine animals (2-3 months old) per genotype and per treatment were used in these experiments. Each animal received a single intraperitoneal injection of $100 \mu \mathrm{l}$ of PBS with $2 \mathrm{mmol}$ of NMDA, $1 \mathrm{nmol}$ of Kp10, or PBS only. One hundred microliters of blood from a tail vein was collected $10 \mathrm{~min}$ after injection. Blood was processed as for prepubertal animals, and plasma supernatant samples were stored at $-20^{\circ} \mathrm{C}$ until assayed. Two hours after injection, mice were deeply anesthetized with pentobarbital and intracardially perfused with $20 \mathrm{ml}$ of $4 \%$ paraformaldehyde in PBS, pH 7.4. Brains were removed and incubated for $1 \mathrm{~h}$ in the same fixative and placed in PBS for sectioning.

\section{Central injection protocols}

Four to nine adult mice were used per genotype and per treatment group. Animals were anesthetized with isoflurane $/ \mathrm{O}_{2}$ and placed on a stereotaxic frame (David Kopf Instruments) on a heat pad at $37^{\circ} \mathrm{C}$ to maintain a normal body temperature. A tail vein blood sample of $100 \mu \mathrm{l}$ was collected before surgery from which $50 \mu \mathrm{l}$ of plasma was obtained and kept at $-20^{\circ} \mathrm{C}$. Each genotype received one single intracerebroventricular $2 \mu$ injection of $7 \mathrm{nmol}$ of NMDA, $1 \mathrm{nmol}$ of Kp10, or PBS only by using a 30 gauge Hamilton syringe. The stereotaxic coordinates for the injection site in the lateral ventricle were $-0.9 \mathrm{~mm}$ anteroposterior and $1.4 \mathrm{~mm}$ lateral to the bregma and $2.0 \mathrm{~mm}$ from the skull surface according to the Paxinos Mouse brain atlas (Franklin and Paxinos, 2001). Animals were kept in place until a second tail vein blood collection of $100 \mu \mathrm{l}$
10 min after injection. Then, animals were kept under anesthesia in a separate warmed box with isoflurane $/ \mathrm{O}_{2}$ until perfusion. Mice were finally perfused $2 \mathrm{~h}$ after injection with $4 \%$ paraformaldehyde solution under deep anesthesia with pentobarbital, and the brain was processed as described above.

In a second series of intracerebroventricular injection experiments investigating the neuronal population responsive to NMDA, four animals per genotype and per treatment group were injected with either PBS or NMDA in the same experimental conditions as described above with the only difference that no blood was collected.

\section{Luteinizing hormone assay}

Plasma LH was assayed using an ELISA (Endocrine Technologies) with a sensitivity of $0.3 \mathrm{ng} / \mathrm{ml}$ and $7 \%$ intra-assay and $10 \%$ interassay coefficients of variation. Plasma samples from vena cava were assayed in duplicate, but samples from tail vein bleeds were assayed in simplicate because of a limited sample volume.

\section{Immunocytochemistry}

Free-floating, dual-label chromogen immunocytochemistry was undertaken as reported previously (Wintermantel et al., 2006; Clarkson et al., 2008). Brains were cut as $40 \mu \mathrm{m}$ free-floating coronal sections using a vibratome (VT1000S; Leica). Sections containing GnRH neurons were taken from the region of the medial septum through to the caudal hypothalamus. Sections were treated with $3 \%$ hydrogen peroxide for $10 \mathrm{~min}$ to quench endogenous peroxidase activity and then washed in Trisbuffered saline (TBS) ( $0.5 \mathrm{~m}$ Tris and $0.15 \mathrm{~m}$ sodium chloride, $\mathrm{pH} 7.6$ ). For the first immunolabeling, sections were incubated for $16 \mathrm{~h}$ at $4^{\circ} \mathrm{C}$ with a primary rabbit polyclonal antisera directed against c-Fos at 1:1000 in TBS containing $0.3 \%$ Triton X-100 (TBS-T) and 5\% normal goat serum. Sections were then incubated with biotinylated anti-rabbit IgG at 1:500 in TBS-T with 5\% normal goat serum for $1 \mathrm{~h}$ at room temperature. After subsequent washing in TBS, the sections were incubated in Vectastain ABC avidin-peroxidase (Vector Laboratories) at 1:100 in TBS-T for $1 \mathrm{~h}$ at room temperature. Immunoreactivity was revealed using glucose-oxidase, nickel-enhanced diaminobenzidine hydrochloride (DAB) that resulted in a black precipitate within the nucleus of the labeled cell. For the second immunolabeling, sections were washed in 3\% hydrogen peroxide to quench any remaining peroxidase, washed in TBS, and then incubated with polyclonal rabbit anti-GnRH (1:3000), anti-nNOS (1: $250)$, or anti-TH (1:1000) in TBS-T containing $5 \%$ goat serum for $16 \mathrm{~h}$ at $4^{\circ} \mathrm{C}$. Sections were then incubated in peroxidase-labeled anti-rabbit IgG (1:500) in TBS-T with 5\% normal goat serum for $1 \mathrm{~h}$ at room temperature. Immunoreactivity was revealed using glucose-oxidase, DAB without nickel to generate a brown precipitate within the cytoplasm. Brain sections were mounted on slides, dehydrated, and coverslipped with DPX (44581; Sigma-Aldrich).

\section{5-Bromo-4-chloro-3-indolyl- $\beta$-D-galactosidase histochemistry and c-Fos immunocytochemistry}

Free-floating sections of $40 \mu \mathrm{m}$ thickness were performed as described above in a 1:3 series. A set of sections containing the arcuate nucleus were washed in TBS and placed in 2\% 5-bromo-4-chloro-3-indolyl- $\beta$-Dgalactosidase (X-gal) solution [ $2 \mathrm{~mm} \mathrm{MgCl}_{2}, 4 \mathrm{~mm} \mathrm{~K}_{3} \mathrm{Fe}(\mathrm{CN})_{6}, 4 \mathrm{~mm}$ $\mathrm{K}_{4} \mathrm{Fe}(\mathrm{CN})_{6}$, and $4 \mathrm{mg} / \mathrm{ml} \mathrm{X}$-gal] overnight at room temperature. After TBS washes, sections were treated with $3 \%$ hydrogen peroxide for 10 min, washed in TBS, and then incubated for $16 \mathrm{~h}$ at $4^{\circ} \mathrm{C}$ with rabbit anti-c-Fos (1:1000) in TBS-T plus 5\% normal goat serum. Sections were then incubated in peroxidase-labeled anti-rabbit IgG (1:500) in TBS-T plus 5\% normal goat serum for $1 \mathrm{~h}$ at room temperature. After TBS washes, immunoreactivity was revealed using glucose-oxidase and DAB that resulted in a brown precipitate within the nucleus. Brain sections were mounted on slides and coverslipped using an aqueous mountant Hydromount (HS-106; National Diagnostics).

\section{Immunocytochemistry analysis}

Sections were examined using an Axioscope 2 plus microscope (Carl Zeiss) using bright-field microscopy. Analysis of the double-labeled tissue was undertaken by counting the number of single-labeled (brown cytoplasm only) and dual-labeled (brown cytoplasm and black nucleus) 
A

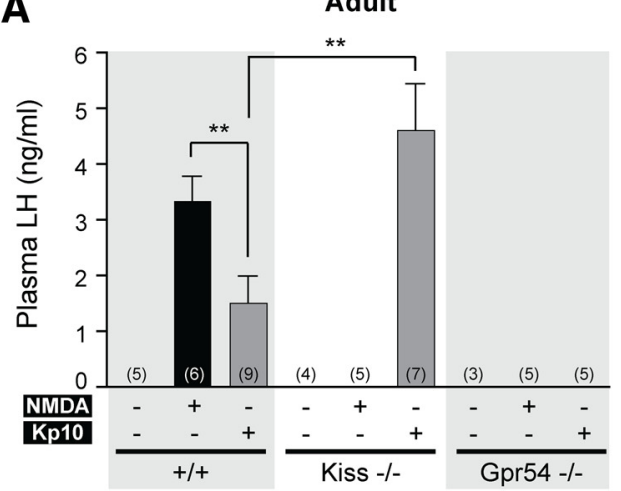

B

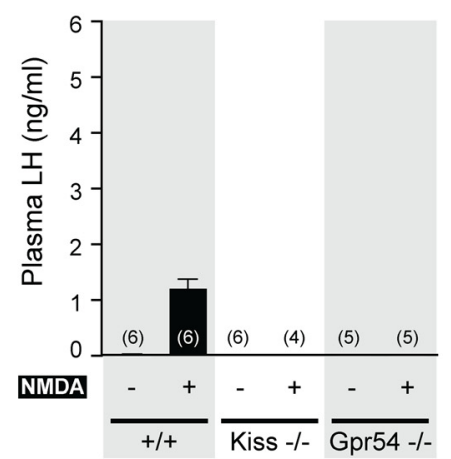

C

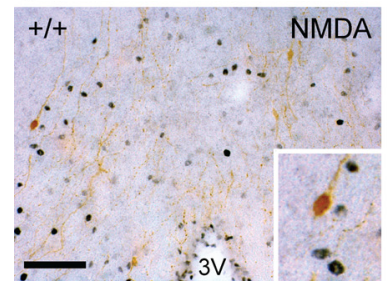

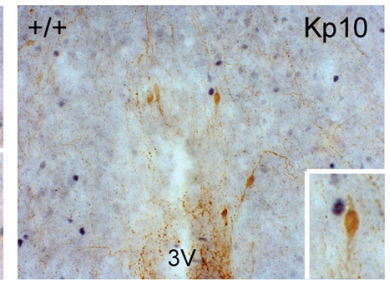

Figure 1. Absence of $\mathrm{LH}$ release after peripheral NMDA injection in Kiss7- and Gpr54-null mice. $\boldsymbol{A}$, Bar graph showing the mean \pm SEM of LH levels in wild-type (+/+), Kiss1-null (Kiss - /-), and Gpr54-null (Gpr54-/-) adult male mice 10 min after PBS, NMDA, or Kp10 intraperitoneal injection. $\boldsymbol{B}$, Bar graph showing the mean \pm SEM of plasma LH levels in prepubertal mice of each genotype 10 min after PBS, NMDA, or Kp10 intraperitoneal injection. ${ }^{* *} p<0.01$ (one-way ANOVA, followed by StudentNewman-Keuls test). Numbers in brackets indicate animal number used in each treatment group. $\boldsymbol{C}$, Representative coronal sections of dual-labeled immunocytochemistry showing the absence of c-Fos staining (black nuclei) in GnRH neurons (brown) in hypothalamus from wild-type or Kiss1-null mice that showed high plasma LH after peripheral stimulation with NMDA (left) or Kp10 (middle and right). Scale bar, $100 \mu \mathrm{m}$. All photographs are the same scale. Inset box is $4 \times$ magnification. 3V, Third ventricle.

neurons. The examiner was not aware of the genotype and treatment at the time of counting. For GnRH/c-Fos dual labeling, all sections with GnRH neurons were counted. GnRH neuron subpopulations were separated into two (Herbison et al., 2010): the medial septum plus the diagonal band of Broca (DBB), i.e., the most anterior and caudal GnRH neurons; and the vascular organ of the lamina terminalis (OVLT) plus the rostral preoptic area (POA), which is the most ventral and posterior $\mathrm{GnRH}$ neurons, corresponding to plates 22-30 of the Mouse Brain Atlas (Franklin and Paxinos, 2001). For TH/c-Fos and nNOS/c-Fos dual labeling, one of three sections were stained. For $\mathrm{TH}$, the regions of the anteroventral paraventricular nucleus (AVPV) and periventricular nucleus $(\mathrm{PeN})$ were analyzed. For nNOS, the following regions were considered: AVPV, median preoptic nucleus (MnPO), medial preoptic nucleus (MPO), medial septal nucleus (MS), and OVLT. One section at each of these regions was analyzed.

\section{Statistics}

The differences between several groups were analyzed by one-way ANOVA, followed with Student-Newman-Keuls multiple comparison test for unequal replication. The comparison between two groups was subjected to an unpaired $t$ test.

Plasma LH values measured before intracerebroventricular injection were not entered in statistical tests because of the very low values, often under the detection limit of the ELISA, for both genotypes.
A
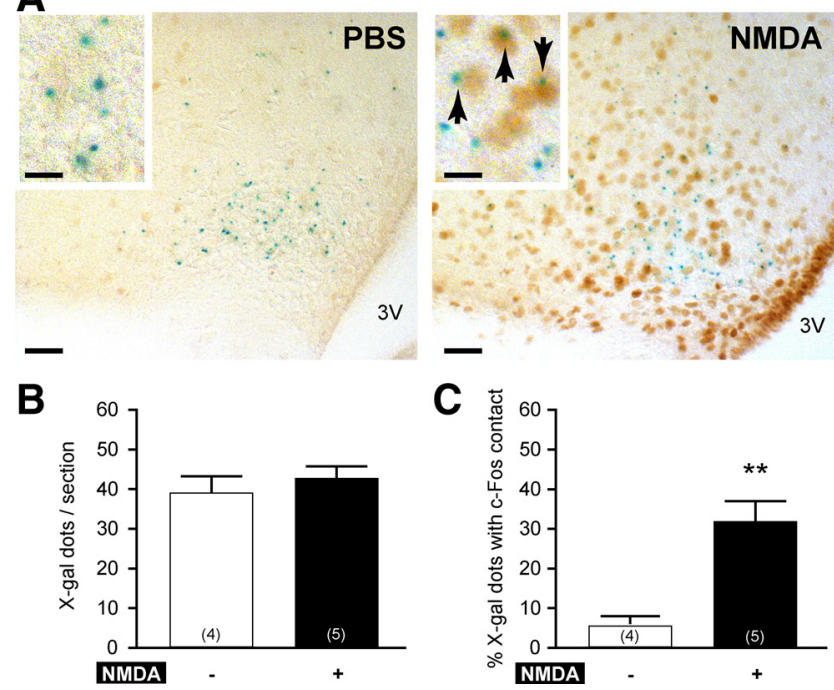

Figure 2. Activation of kisspeptin neurons in the Arc after NMDA intraperitoneal injection in Kiss1-null mice. Kisspeptin neurons were identified by LacZ expression revealed by X-gal staining. $\boldsymbol{A}$, Representative coronal section showing X-gal-positive cells (blue dots) and c-Fosimmunopositive nuclei (brown staining) in the Arc. NMDA intraperitoneal injection induced intense c-Fos staining (right) compared with PBS (left). Inset boxes are magnified views, and arrows indicate X-gal cells with c-Fos staining. Scale bars: $50 \mu \mathrm{m}$ for low magnification; $10 \mu \mathrm{m}$ for high magnification. 3V, Third ventricle. $B$, Bar graph showing the mean \pm SEM number of X-gal-positive cells per section after PBS $(-)$ or NMDA $(+)$ intraperitoneal injection. Numbers in brackets indicate animal number used in each treatment group. $C$, Bar graph showing the mean \pm SEM percentage of X-gal-positive cells with c-Fos per section after PBS (-) or NMDA $(+)$ intraperitoneal injection. ${ }^{* *} p=0.0025$ (unpaired $t$ test).

\section{Results}

Peripheral NMDA injection requires both kisspeptin and GPR54 to stimulate $\mathrm{LH}$ release in gonadally intact adult male mice

The aim of this first series of experiments was to investigate the stimulating effect of NMDA on LH release in adult male mice lacking the Kiss1 or Gpr54 gene expression. As described previously (Mahesh and Brann, 2005), NMDA is a potent stimulator of $\mathrm{LH}$ release via activation of $\mathrm{GnRH}$ neurons. Intraperitoneal injection of NMDA in wild-type male mice induced $\mathrm{LH}$ release $(3.33 \pm 0.44 \mathrm{ng} / \mathrm{ml}$ ) compared with PBS injection (undetectable in the assay) (Fig. 1A). LH release was not observed in mutant male mice of either genotype (values were below the detection limit of the assay). In contrast, in Kiss1-null mice, intraperitoneal injection of Kp10 induced a robust $\mathrm{LH}$ release $(4.60 \pm 0.83 \mathrm{ng} /$ ml) compared with PBS (Fig. $1 A$ ). Kp10 induced a lower LH release in wild-type $(1.49 \pm 0.48 \mathrm{ng} / \mathrm{ml})$ than in the Kiss 1 mutants $(p<0.01)$ or other wild-type mice treated with NMDA $(p<$ $0.01)$. As expected, Kp10 intraperitoneal injection showed no effect on LH release in Gpr54-null mice (Fig. $1 \mathrm{~A}$ ).

Dual-label immunocytochemistry for GnRH and c-Fos in NMDA-treated adult male mice showed absence of c-Fos staining in GnRH cells after peripheral NMDA injection (Fig. 1C). GnRH neurons also did not express c-Fos after peripheral Kp10 injection in wild-type and Kiss1-null mice (Fig. 1C), although these groups positively responded to Kp10 stimulation by releasing LH (Fig. 1A).

These data show that the kisspeptin/GPR54 pathway is required for the NMDA-induced LH release when NMDA is in- 
jected peripherally into adult male mice. These data also indicate that peripherally injected NMDA or Kp10 do not stimulate c-Fos expression within GnRH neurons even when $\mathrm{LH}$ release is observed.

\section{Peripheral NMDA injection requires} both kisspeptin and GPR54 to stimulate $\mathrm{LH}$ release in prepubertal male mice

The failure of peripheral injection of NMDA to stimulate $\mathrm{LH}$ release in mutant mice could be attributed to the low testosterone levels found in the mutant animals (Seminara et al., 2003; d'Anglemont de Tassigny et al., 2007b). In this experiment, we used prepubertal males to investigate the plasma LH response to NMDA between Kiss1-null, Gpr54-null, and wildtype males, all having low testosterone levels (Selmanoff et al., 1977). Intraperitoneal injection of NMDA in wild-type mice induced LH release $(1.19 \pm 0.16 \mathrm{ng} /$ $\mathrm{ml}, n=6$ ), whereas LH levels were below the detection limit of $0.3 \mathrm{ng} / \mathrm{ml}$ in both NMDA-treated mutants $(n=4-5)$ and PBS-treated mice $(n=5-6)$ (Fig. $1 B)$. These data indicate that the absence of $\mathrm{LH}$ release in prepubertal mutant mice in response to peripheral NMDA stimulation is attributable to the absence of the GPR54/kisspeptin pathway rather than low sex steroid levels.

\section{Peripheral NMDA injection induces} c-Fos expression in kisspeptin neurons in intact adult male mice

To further explore the action of NMDA on LH release, we performed immunocytochemistry for c-Fos coupled with X-gal histochemistry, which was used as a marker for the Kiss1 gene expression, because it is difficult to visualize the kisspeptin cell bodies with normal immunocytochemistry. Therefore, we used Kiss1-null adult male mice in which the $L a c Z$ reporter gene allows Kiss1 neuron visualization by X-gal staining (d'Anglemont de Tassigny et al., 2007b). The blue X-gal reaction product is found predominantly as one or two dot-like structures within the cytoplasm of the expressing cells as observed previously by others and us (Friedrich et al., 1993; Herbison et al., 2010) (Fig. 2A). A blind test showed no difference $(p=0.44)$ between PBS $(39.2 \pm 3.7)$ and NMDA $(42.8 \pm 2.6)$ peripheral injections in the average number of $\mathrm{X}$-gal dots per section of the Arc (Fig. 2 B). Kisspeptin neurons with c-Fos expression were identified by the presence of one or more X-gal dots with a visible contact with a c-Fos immunopositive nucleus in a same focus plane. Quantitative analysis of X-gal-positive dots with c-Fos contact showed a significantly $(p=0.0025)$ higher percentage of X-gal-positive cells with c-Fos with NMDA $(31.9 \pm 4.8 \%)$ compared with PBS $(5.6 \pm 2.0 \%)$ (Fig. $2 C$ ). These results suggest that NMDA

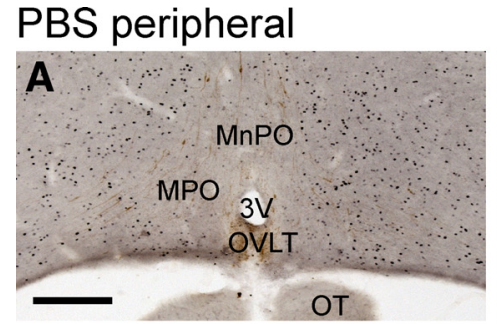

\section{NMDA peripheral}
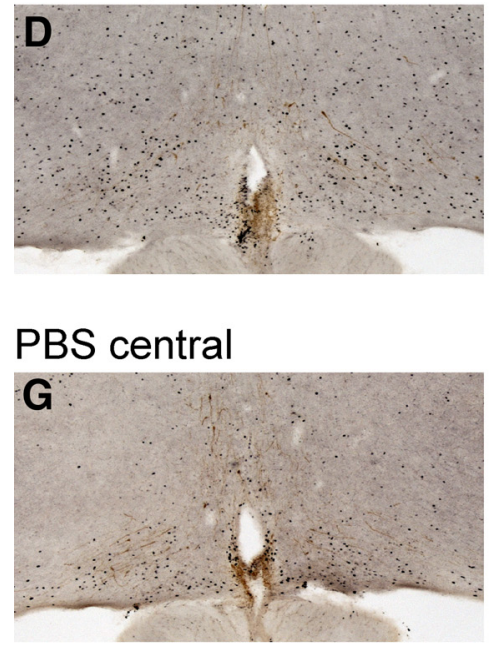

NMDA central
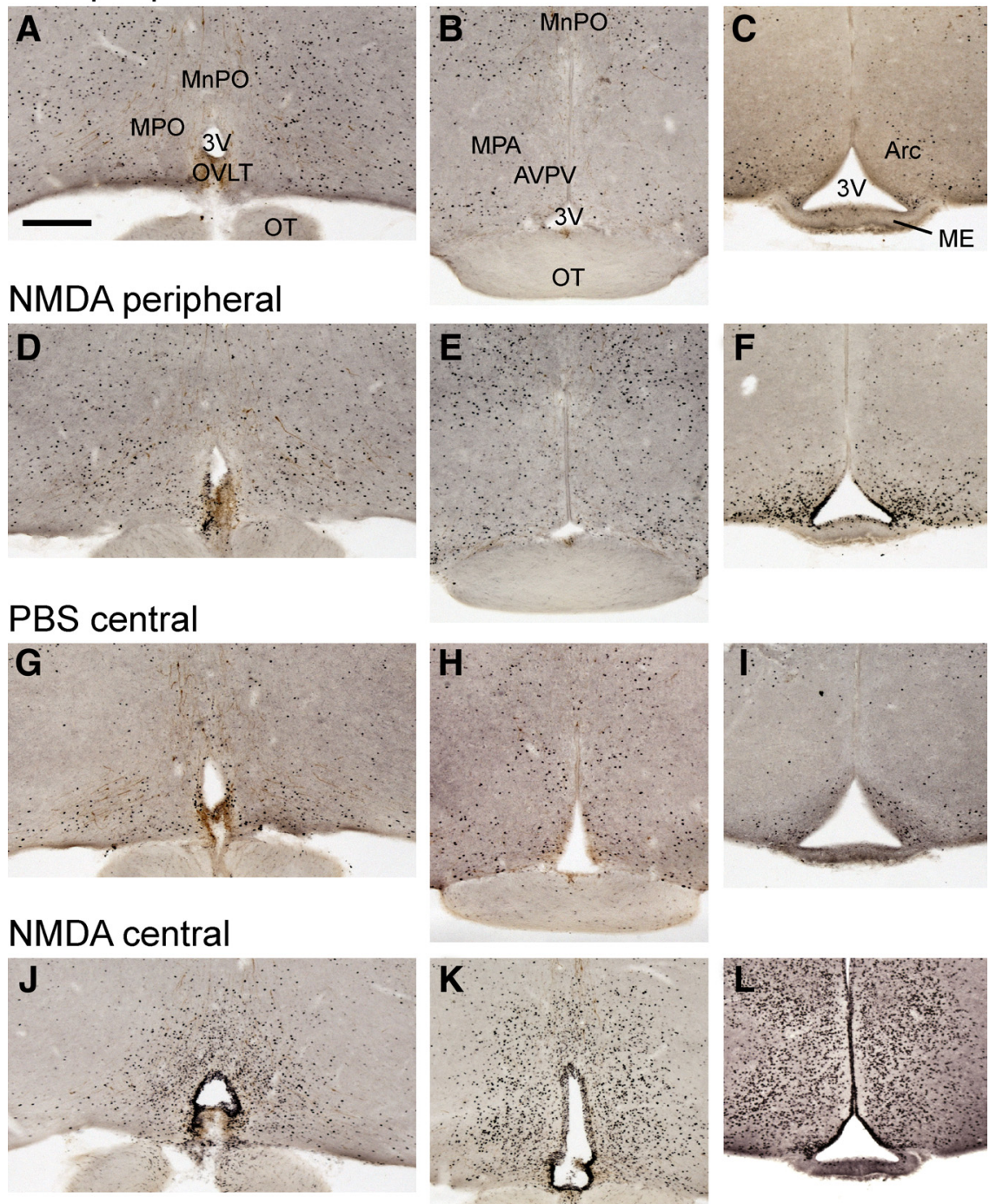

Figure 3. Induction of c-Fos after peripheral or central injection of NMDA in wild-type mice. Representative low-magnification photomicrographs showing immunocytochemical c-Fos staining (black nuclei) in three different coronal sections. $\boldsymbol{A}-\boldsymbol{C}, \mathrm{c}-\mathrm{Fo}$ staining $2 \mathrm{~h}$ after PBS intraperitoneal injection. $\boldsymbol{D}-\boldsymbol{F}, \mathbf{c}-$ Fos staining $2 \mathrm{~h}$ after NMDA intraperitoneal injection. Note the intense labeling in Arc and moderate labeling in OVLT. G-I, c-Fos staining $2 \mathrm{~h}$ after PBS intracerebroventricular injection. Staining is very intense in every periventricular hypothalamic region. Regions containing $\mathrm{GnRH}$ cell bodies, such as MnP0, MP0, and MPA (in light brown in $\boldsymbol{A}, \boldsymbol{D}, \boldsymbol{G}, \boldsymbol{J})$, show high concentration of black nuclei, indicating activated cells, only after intracerebroventricular NMDA Regions known to contain Kp neurons, such as the Arc, show high c-Fos staining after intraperitoneal and intracerebroventricular $\operatorname{NMDA}(\boldsymbol{F}, \boldsymbol{L})$. The sexually dimorphic AVPV containing a Kp neuron population has high c-Fos staining after intracerebroventricular NMDA exclusively $(\boldsymbol{K})$. 3V, Third ventricle; 0T, optic tract. Scale bar, $600 \mu \mathrm{m}$. All photographs are the same scale.

induces LH release partly via kisspeptin neurons activation in the arcuate nucleus.

\section{Differences in c-Fos induction in the hypothalamus between} central and peripheral NMDA administration

It is not clear to what extent NMDA can cross the blood-brain barrier (BBB) after peripheral injection. c-Fos activation in the Arc region but not the OVLT/POA regions after peripheral NMDA injection suggests limited access to some hypothalamic nuclei by this route of administration. To overcome this issue, NMDA, Kp10, or PBS were injected directly into the lateral ventricle to ensure broad diffusion into the circumventricular regions. 
After central NMDA injection, we observed c-Fos-immunoreactive cells in the following hypothalamic regions surrounding the third ventricle (Fig. $3 J-L$ ): anterodorsal preoptic nucleus, Arc, AVPV, lateral preoptic nucleus, MnPO, medial preoptic area (MPA), MPO, OVLT, and PeN. The Arc was the only hypothalamic region clearly showing high c-Fos immunoreactivity after peripheral NMDA injection compared with PBS injection (Fig. 3C,F). These data indicate that NMDA stimulates a larger population of hypothalamic cells after central injection compared with peripheral injection. NMDA can potentially reach the GnRH neurons when injected centrally but not after peripheral injection.

\section{Central injection of NMDA provokes LH release but no c-Fos expression in GnRH neurons in both wild-type and mutant mice}

The ability of NMDA to activate GnRH neurons and generate $\mathrm{LH}$ release was evaluated in Kiss1-null and Gpr54-null adult male mice along with their wild-type littermates. Plasma LH was measured before and $10 \mathrm{~min}$ after central injection. Kp10 was used as a control for c-Fos activation in GnRH neurons.

In wild-type animals, plasma LH was significantly higher $(p<$ $0.01)$ after NMDA injection ( $3.24 \pm 0.50 \mathrm{ng} / \mathrm{ml}, n=9)$ compared with PBS injection $(0.93 \pm 0.35 \mathrm{ng} / \mathrm{ml}, n=7)$ (Fig. $4 A)$. Plasma LH from Kiss1-null mice was significantly higher $(p<0.001)$ after NMDA injection ( $5.68 \pm 0.84 \mathrm{ng} / \mathrm{ml}, n=5)$ compared with PBS-treated Kiss1-null mice $(0.38 \pm 0.24, n=4)$. Plasma LH from Gpr54-null mice was also significantly higher $(p<0.05)$ after NMDA treatment $(2.66 \pm 0.64 \mathrm{ng} / \mathrm{ml}, n=8)$ compared with the same genotype after PBS injection $(0.45 \pm 0.17 \mathrm{ng} / \mathrm{ml}$, $n=7)$. A comparison test between the different genotypes showed that, after NMDA injection, the LH levels were significantly higher in Kiss1-null mice compared with either wild-type or Gpr54-null mice ( $p<0.05$ ) (Fig. $4 A$ ).

The percentage of GnRH cells with c-Fos immunoreactivity was calculated in two different regions: the MS/DBB and the OVLT/POA. Because we uncovered two main areas of Gpr54 gene expression in postnatal GnRH neurons (Herbison et al., 2010), we separated these two topographically defined subpopulations of $\mathrm{GnRH}$ neurons (Herbison, 2006) to discriminate any difference that might occur. We found that the number of duallabeled c-Fos plus GnRH neurons was low in both NMDAtreated (Fig. $5 B, E, H$ ) and PBS-treated (Fig. 5A,D,G) animals. The quantification showed no significant difference between NMDA-treated and PBS-treated animals in wild-type or Kiss1null mice in the two GnRH neuron subpopulations (Fig. 6). However, we observed a significantly higher $(p<0.05)$ percentage of GnRH neurons with c-Fos in PBS treated Gpr54 mutant mice compared with NMDA in the OVLT/POA subpopulation only (Fig. 6).

\section{Central injection of Kp10 provokes $\mathrm{LH}$ release associated with c-Fos expression in GnRH neurons in both wild-type and Kiss1-null mice}

We used Kp10 to assess whether our protocol for intracerebroventricular injection was appropriate to provoke c-Fos expression in GnRH neurons. Kp10 was injected centrally at a dose of $1 \mathrm{nmol}$ similar to that used by others to induce $\mathrm{GnRH}$ neuron activation associated with $\mathrm{LH}$ release (Navarro et al., 2005).

In wild-type animals, the average plasma LH was significantly higher $(p<0.05)$ after Kp10 injection $(3.26 \pm 0.77 \mathrm{ng} / \mathrm{ml}, n=7)$ than after PBS $(0.93 \pm 0.35 \mathrm{ng} / \mathrm{ml}, n=7)$ (Fig. $4 B)$. Plasma LH
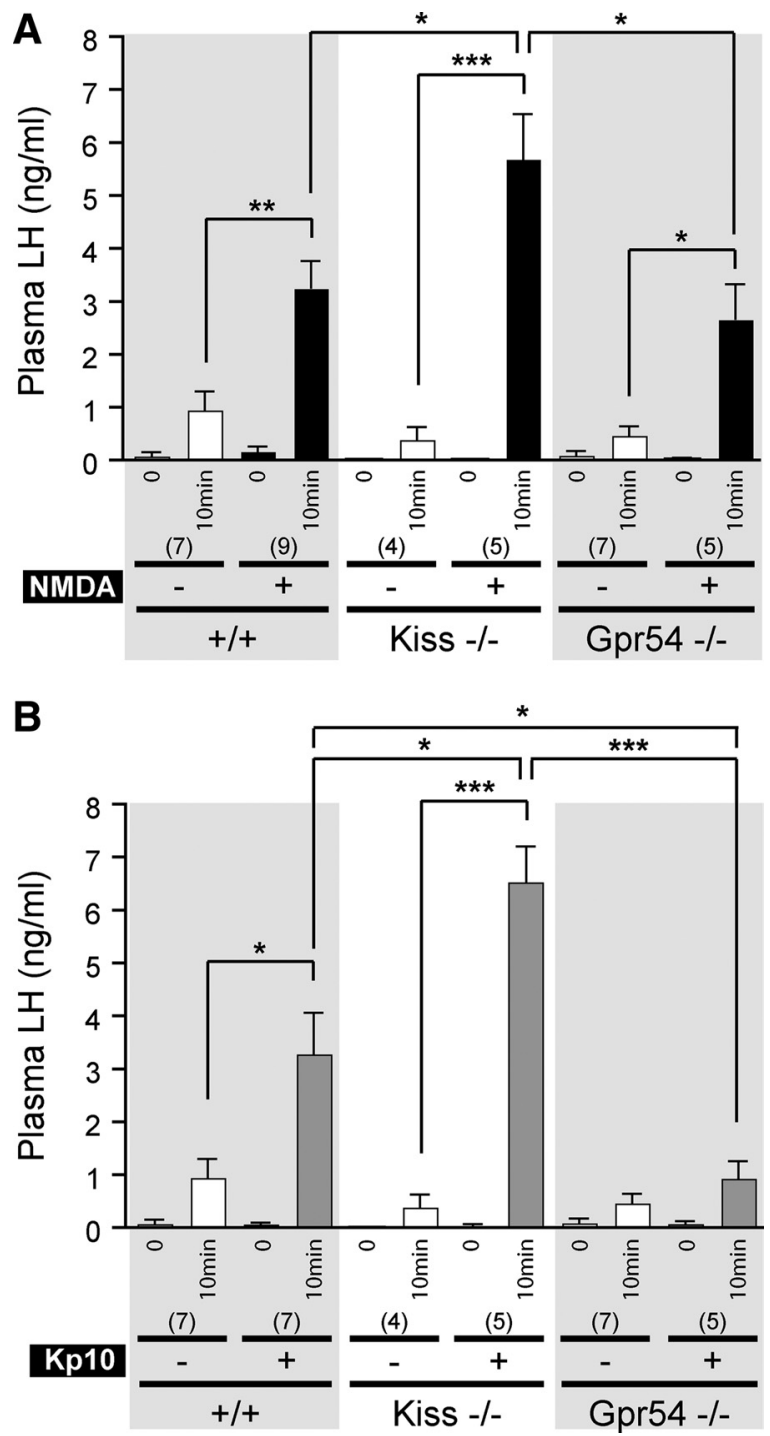

Figure 4. Effect of central NMDA or Kp10 injection on LH release in Kiss1- and Gpr54-null mice. $\boldsymbol{A}$, Bar graph showing the mean \pm SEM of LH levels in wild-type $(+/+)$, Kiss1-null (Kiss - /-), and Gpr54-null (Gpr54-/-) mice before (0) and 10 min after PBS (-) or NMDA $(+)$ intracerebroventricular injection. $\boldsymbol{B}$, Bar graph showing the mean \pm SEM of LH levels in mice of each genotype, before $(0)$ and 10 min after PBS $(-)$ or Kp10 $(+)$ intracerebroventricular injection. ${ }^{*} p<0.05,{ }^{* *} p<0.01,{ }^{* * *} p<0.001,10$ min after PBS vs 10 min after NMDA or Kp10 in same genotype (unpaired $t$ test), or 10 min after either NMDA or Kp10 between the three genotypes (one-way ANOVA, followed with Student-Newman-Keuls test). Numbers in brackets indicate animal number used in each condition.

from Kp10-stimulated Kiss1-null mice $(6.51 \pm 0.67 \mathrm{ng} / \mathrm{ml}, n=5)$ was significantly higher $(p<0.001)$ than Kiss1-null mice treated with PBS $(0.38 \pm 0.24 \mathrm{ng} / \mathrm{ml}, n=4)$. As expected, Gpr54-null mice showed no LH secretion after central injection of Kp10 ( $p=$ 0.200 ). In these experiments, the values before injection were not used for statistical analysis because they were below the detection limits in any of the treatment groups.

Kp10 induced significant c-Fos expression in GnRH neurons in both wild-type mice $(27.3 \pm 3.4 \%$ in $\mathrm{MS} / \mathrm{DBB}, p<$ $0.001 ; 47.7 \pm 2.6 \%$ in OVLT/POA, $p<0.001)$ and Kiss 1 -null mice $(41.3 \pm 8.5 \%$ in MS/DBB, $p<0.01 ; 51.3 \pm 7.8 \%$ in OVLT/POA, $p<0.001)$ compared with PBS treatment $(3.6 \pm$ 1.3 and $5.1 \pm 1.9 \%$, respectively, in MS/DBB; $2.8 \pm 0.9$ and $5.2 \pm 3.4 \%$, respectively, in OVLT/POA). In the MS/DBB, the percentage of $\mathrm{GnRH}$ neurons with c-Fos immunoreactivity 
after Kp10 injection was significantly higher $(p<0.01)$ in Kiss1-null mice than wild-type animals (Fig. 6). Kp10 failed to induce c-Fos expression in Gpr54-null mice $(3.2 \pm 1.5 \%$ in MS/ $\mathrm{DBB}$ and $4.0 \pm 1.4 \%$ in OVLT/POA vs $3.3 \pm 1.2$ and $2.3 \pm 0.6 \%$, respectively, in PBS animals) (Fig. 6). Thus, Kp10treated Kiss1-null mice $(p<0.001$ for both MS/DBB and OVLT/POA) and wild-type mice $(p<0.01$ for MS/DBB, $p<0.001$ for OVLT/POA) had higher percentage of GnRH neurons with c-Fos immunoreactivity than Gpr54-null mice.

\section{Central injection of NMDA induces c-Fos expression in catecholaminergic and nitric oxidergic neurons in both wild-type and mutant mice}

To explore the kisspeptin-independent action of NMDA on LH release, we performed intracerebroventricular injections of NMDA in the three genotypes and evaluated the activation of two hypothalamic neuronal populations that are classical candidates in $\mathrm{GnRH}$ neuron regulation: catecholamine and NO-containing neurons (Mahesh and Brann, 2005; Herbison, 2006). We used the same strategy as in previous experiments, consisting of dual labeling for c-Fos and the enzymes catalyzing the production of catecholamines: $\mathrm{TH}$ or NO, namely nNOS. Immunostaining revealed populations of $\mathrm{TH}$ neurons in the hypothalamus mainly in the Arc, PeN, and AVPV. We considered only the $\mathrm{PeN}$ and AVPV regions for quantification because the effect of NMDA in the Arc requires kisspeptin signaling to stimulate $\mathrm{LH}$ release, as shown in previous results in the present study. Dual-labeling immunocytochemistry for c-Fos and $\mathrm{TH}$ showed a significant increase $(p<0.001)$ of the percentage of $\mathrm{TH}$ neurons with c-Fos in wild-type, Gpr54-null, and Kiss1null mice after NMDA intracerebroventricular injection $(59.5 \pm 5.8,58.6 \pm 9.1$, and $74.5 \pm 1.5 \%$, respectively) compared with PBS (4.2 $\pm 1.0,5.5 \pm 0.8$, and $7.5 \pm$ $1.4 \%$, respectively) (Fig. $7 A, B$ ).

nNOS neurons are widespread in the hypothalamus with higher density in the AVPV, MnPO, MPO, MS, and OVLT. We counted one field at $20 \times$ magnification for each region and grouped the values to obtain an average percentage of nNOS with c-Fos per animal. The percentage of nNOS plus c-Fos neurons in wild-type, Gpr54-null, and Kiss1-null mice after

NMDA intracerebroventricular injection $(48.2 \pm 7.5,59.0 \pm 3.0$, and $53.2 \pm 2.7 \%$, respectively) was significantly higher $(p<$ $0.001)$ than PBS $(5.8 \pm 1.0,10.6 \pm 1.8$, and $14.3 \pm 4.4 \%$, respectively) (Fig. 7C,D).
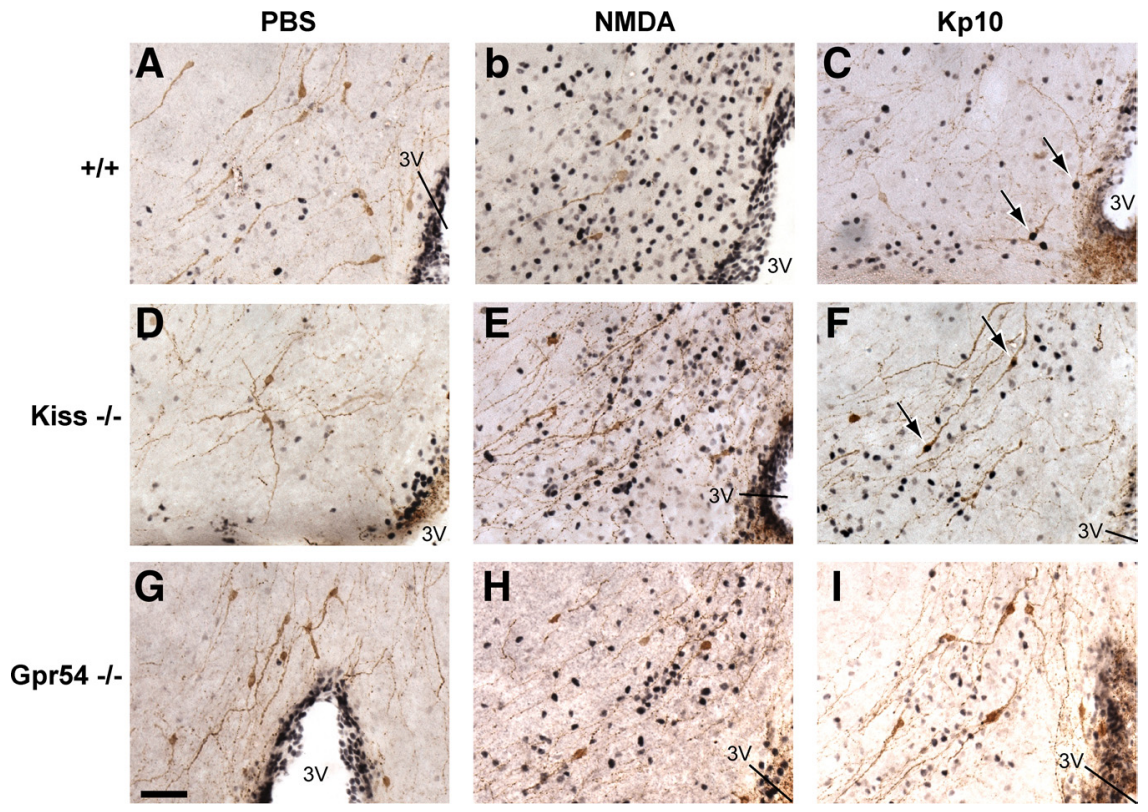

Figure 5. Absence of c-Fos induction in GnRH neurons after central injection of NMDA. Representative photomicrographs of duallabeled immunocytochemistry coronal sections showing GnRH neurons (brown) and c-Fos staining (black nuclei) in the MS/DBB region. $A$, Absence of c-Fos staining in GnRH neurons of PBS-treated wild-type mice. $B$, High c-Fos staining density but absence of c-Fos expression in GnRH neurons of NMDA-treated wild-type mice. C, GnRH neurons expressing c-Fos (arrows) in Kp10-treated wild-type mice. D, Absence of c-Fos staining in GnRH neurons of PBS-treated Kiss1-null mice. $\boldsymbol{E}$, High c-Fos staining density but absence of c-Fos expression in GnRH neurons of NMDA-treated Kiss1-null mice. F, GnRH neurons expressing c-Fos (arrows) in Kp10-treated Kiss1-null mice. G, Absence of c-Fos staining in GnRH neurons of PBS-treated Gpr54-null mice. $\boldsymbol{H}$, High c-Fos staining density but absence of c-Fos expression in GnRH neurons of NMDA-treated Gpr54-null mice. I, Absence of c-Fos staining in GnRH neurons of Kp10-treated Gpr54-null mice. 3V, Third ventricle. Scale bar, $100 \mu \mathrm{m}$. All photographs are the same scale.
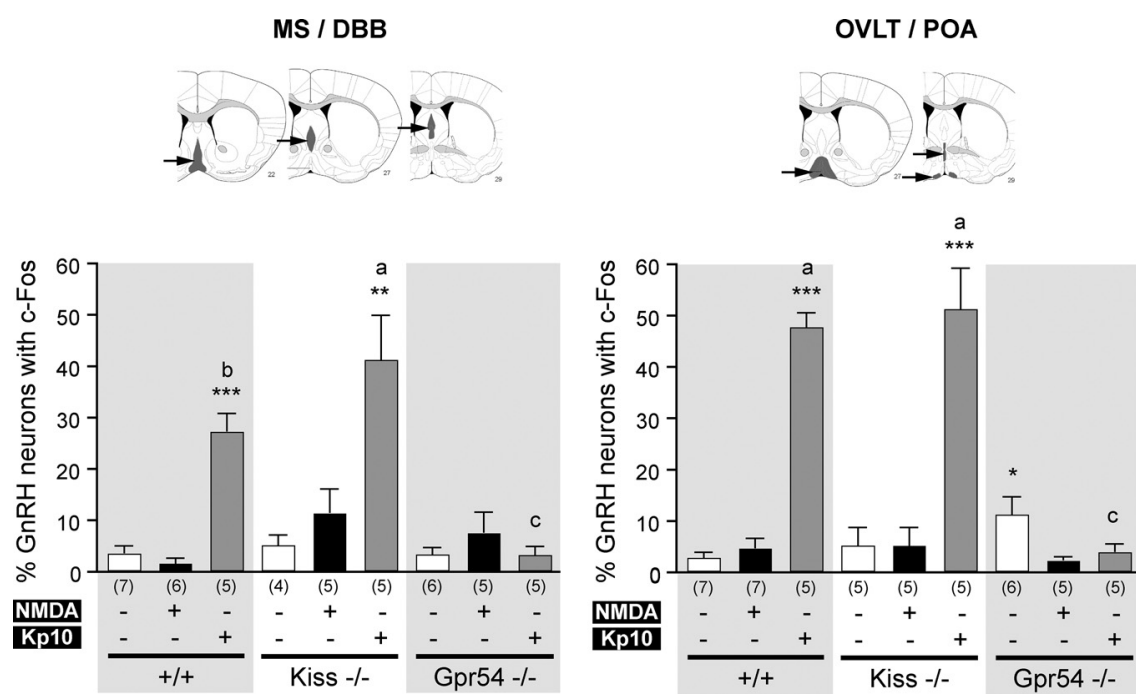

Figure 6. Quantification of GnRH neurons with c-Fos expression after central injections. Bar graphs represent the percentage of GnRH neurons expressing c-Fos (mean \pm SEM) in the MS/DBB (left) or in the OVLT/POA (right) regions. Arrows indicate gray regions on the brain map. In each region, bar graphs show percentage of GnRH neurons (mean $\pm S E M)$ with c-Fos in wild-type $(+/+)$, Kiss1-null (Kiss - / -), and Gpr54-null (Gpr54-/-) mice before (0) and 10 min after PBS (white bars), NMDA (black bars), or Kp10 (gray bars) intracerebroventricular injection. ${ }^{*} p<0.05,{ }^{* *} p<0.01,{ }^{* * *} p<0.001$ when different treatments on same genotype were compared. a vs $c, p<0.001$; b v s $c, p<0.01$; a vs b, not significant when different genotypes were compared with the same treatment in the same subpopulation (one-way ANOVA, followed with Student-Newman-Keuls test in both comparison tests). Numbers in brackets indicate animal number used in each condition.

These data show a potent action of centrally injected NMDA to stimulate hypothalamic catecholaminergic and nitric oxidergic neurons in the absence of Kiss1 or Gpr54 gene expression. 
A

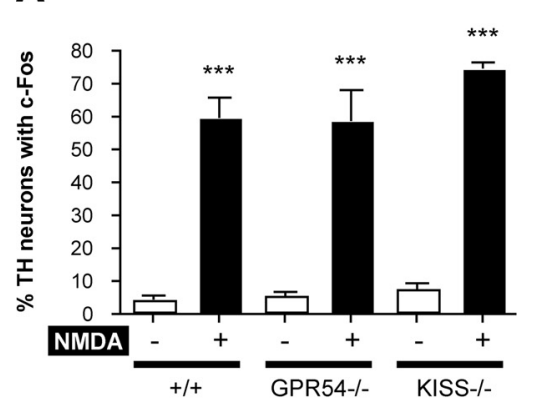

B

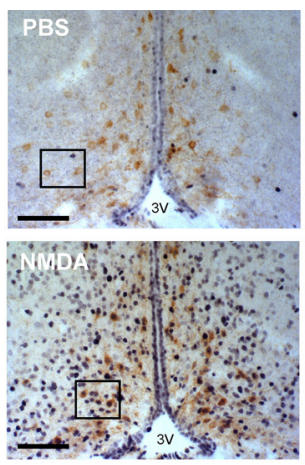

C

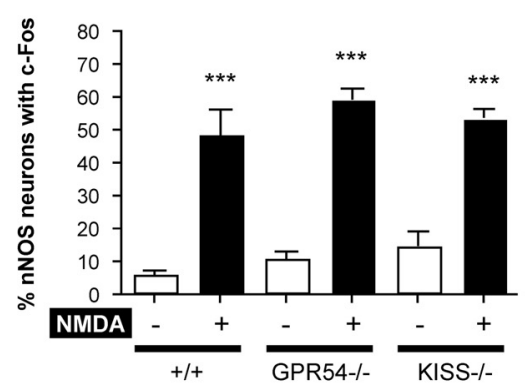

D PBS

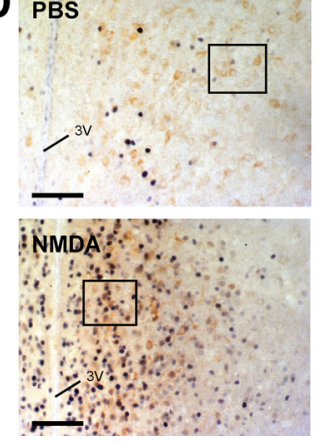

Figure 7. Catecholamine- and nitric oxide-producing neurons are responsive to NMDA in Kiss1 and Gpr54 mutant mice. Catecholamine- and nitric oxide-producing neurons were immunostained for TH and nNOS, respectively. $A$, Bar graph showing the mean \pm SEM percentage of TH neurons counted per section with c-Fos in the AVPV and PeN of wild-type $(+/+)$, Kiss 1 -null (Kiss - /-), and Gpr54-null (Gpr54-/-) mice after PBS (-) or NMDA (+) intracerebroventricular injection. B, Representative dual-labeled immunocytochemistry showing TH (brown cytoplasmic staining) and c-Fos (dark blue nucleic staining) in the AVPV after PBS or NMDA. Arrows indicate TH neurons with c-Fos. C, Bar graph showing the mean \pm SEM percentage of nNOS neurons counted per section with c-Fos in the AVPV, MnP0, MPO, MS, and OVLT of $+/+$, Kiss $-/-$, and Gpr54- - - mice after PBS $(-)$ or NMDA $(+)$ intracerebroventricular injection. $\boldsymbol{D}$, Representative dual-labeled immunocytochemistry showing nNOS (brown cytoplasmic staining) and c-Fos (dark blue nucleic staining) in the MPO after PBS or NMDA. Arrows indicate nNOS neurons with c-Fos. Boxes indicate magnified views of photos on the right. 3V, Third ventricle. Scale bars: $\boldsymbol{B}, 125 \mu \mathrm{m}$ at low magnification and $15 \mu \mathrm{m}$ at high magnification; $\boldsymbol{D}, 150 \mu \mathrm{m}$ at low magnification and $20 \mu \mathrm{m}$ at high magnification. ${ }^{* *} p<0.001$ versus PBS in same genotype (unpaired $t$ test).

\section{Discussion}

We report here a dual effect of NMDA on LH release in mutant mice lacking the Kp/GPR54 signaling pathway. NMDA failed to stimulate LH release in both adult and prepubertal male Kiss1and Gpr54-null mice when administered peripherally, whereas LH release occurred in wild-type mice. Peripheral administration of NMDA induced activation of Kiss1 neurons as shown by our $\mathrm{X}$-gal/c-Fos dual labeling. In contrast, centrally injected NMDA potently stimulated LH release in mutant mice but did not cause significant c-Fos expression in GnRH neurons. In contrast, central injection of Kp10 in wild-type and Kiss1-null mice activated c-Fos in GnRH neurons. However, central injection of NMDA induced c-Fos expression in catecholamine- and nitric oxidesynthesizing neurons. This suggests a $\mathrm{Kp}$-independent pathway through the activation and release of other modulators of GnRH neurons. These data indicate an essential role for $\mathrm{Kp}$ signaling in peripheral NMDA-induced LH release. This essential role is not required for central NMDA action, which successfully induced LH release in mutant mice.

In this study, plasma LH was used as an indicator for GnRH neuronal activation and release. Whereas the presence of GPR54 has been reported in the pituitary gland (Richard et al., 2008), the effects of Kp and NMDA are likely to be upstream of the pituitary because GnRH receptor antagonists prevent both NMDA and Kp stimulation of LH release (Cicero et al., 1988; Gottsch et al., 2004; Navarro et al., 2005).
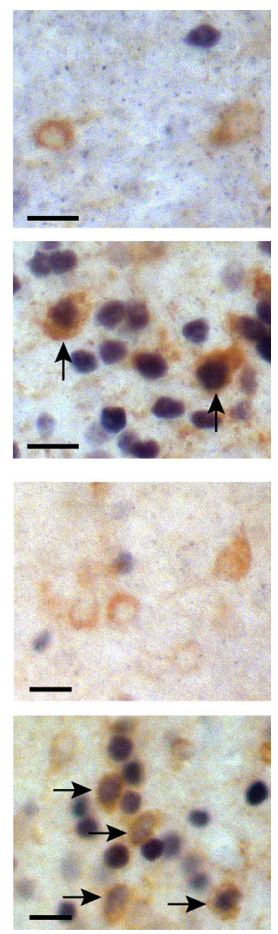

In our first set of experiments, mutant male mice failed to respond to peripheral NMDA stimulation, whereas wild-type mice released LH. This lack of a response to NMDA was independent of pubertal development stage, regardless of low or high testosterone levels (Selmanoff et al., 1977). Peripheral NMDA requires a functional $\mathrm{Kp}$ signaling pathway to stimulate LH release. c-Fos staining indicated that peripheral injection of NMDA can only access neurons in the Arc in which a population of Kp neurons is found in normal male mice (Gottsch et al., 2004; Clarkson et al., 2009). The detection of Kp cell bodies in the Arc is difficult because of the very dense $\mathrm{Kp}$ fiber plexus observed by immunocytochemistry (Clarkson et al., 2009). To investigate the action of NMDA on kisspeptin neurons, we used the properties of our transgenic mice in which $\beta$-galactosidase is targeted to Kiss1-expressing cells. Although the dot-like X-gal staining did not allow whole-cytoplasm visualization, it was sufficiently clear to observe X-gal-positive neurons with c-Fos staining after peripheral NMDA administration. This suggests direct stimulation of Kiss1 neurons by NMDA (Fig. 8A). To our knowledge, no research team has investigated the expression of the NMDA receptor in Kp neurons. There is little evidence that NMDA can act directly at the GnRH nerve terminals in the median eminence (ME) because NMDA receptor-1 mRNA is expressed by GnRH neurons (Ottem et al., 2002). However, data from cultured hypothalamic explant suggest that NMDA action on GnRH secretion takes place in the preoptic area region rather than at the median eminence in which the GnRH nerve terminals project (Bourguignon et al., 1997). We suggest that both NMDA and Kp can act at the ME. The simplest mechanism suggested by our present study is NMDA stimulation of Kp neurons, which then release $\mathrm{Kp}$ to trigger $\mathrm{GnRH}$ secretion, leading to increased plasma LH. This scenario is supported by the presence of Kp fibers in the ME (Decourt et al., 2008; Ramaswamy et al., 2008), and Kp is also released in a pulsatile manner in the stalk-median eminence region of female rhesus monkeys (Keen et al., 2008). We have demonstrated previously that Kp can directly stimulate GnRH secretion from mouse mediobasal hypothalamus explants that contain GnRH nerve terminals but lack GnRH cell bodies (d'Anglemont de Tassigny et al., 2008). However, there is no direct evidence yet of a direct action of Kp at GnRH nerve terminals, although GnRH neurons express Gpr54 in the mouse (Messager et al., 2005; Herbison et al., 2010). We cannot exclude some modulating effect of Kp on other inputs to GnRH neurons, such as dopamine or neuropeptide $\mathrm{Y}$ neurons (Herbison, 2006). Here, the Kiss 1-null mice responded to NMDA stimulation, at least in the kisspeptin neurons, as shown by the $\mathrm{X}$-gal/c-Fos staining. Therefore, it is unlikely that the absence of NMDA-induced LH release in Kiss1 and Gpr54 mutant mice comes from dysfunction of the NMDA receptor.

In contrast to peripheral administration, central injection of NMDA in Kiss 1- and Gpr54-null mice stimulated LH release. The 
A

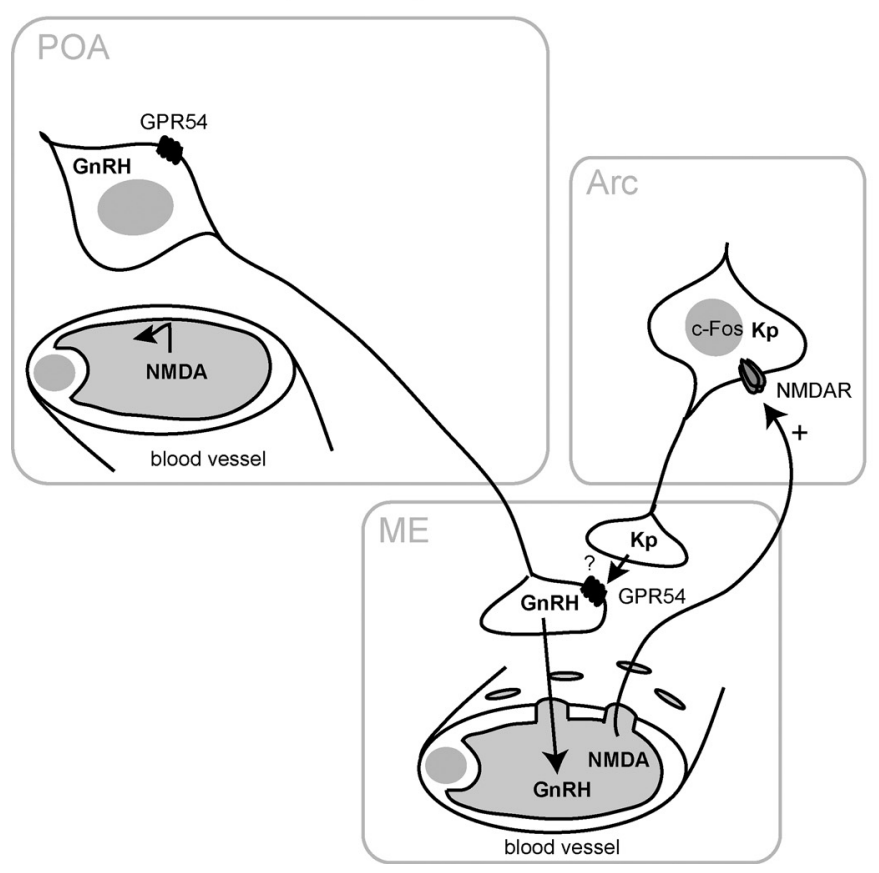

B

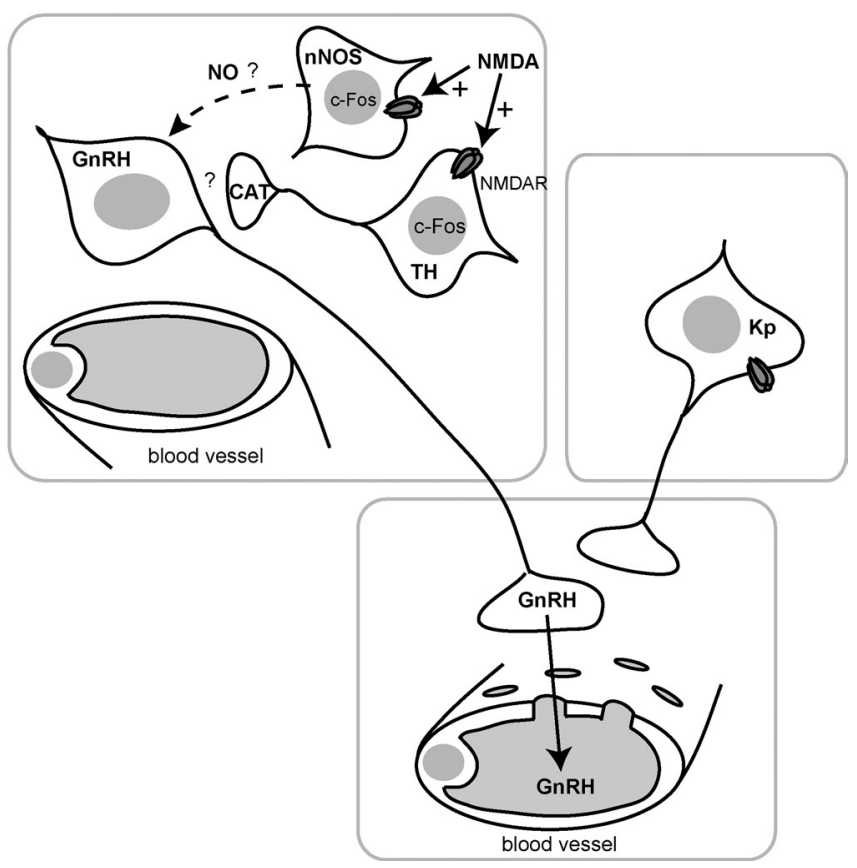

Figure 8. A schematic representation of the possible effect of peripheral versus central injection of NMDA on the GnRH neuronal network. $A$, Peripherally injected NMDA does not reach the POA in which the GnRH neuron cell bodies are located. NMDA can penetrate into the Arc through the fenestrated capillaries of the ME. NMDA requires Kp neuron activation, revealed by c-Fos expression, in the Arc, and Kp release then activates GnRH release from the nerve terminals. B, Central injection of NMDA activates nNOS- and TH-containing neurons in the POA, revealed by c-Fos expression. This may result in production of the diffusible gas NO and the release of catecholamines (CAT), which might stimulate GnRH release. Question mark denotes an undetermined mechanism. NMDAR, NMDA receptor.

key difference between peripheral and central administration was the larger cell population stimulated by NMDA. The NMDA receptor is widely expressed in the rodent hypothalamus (Bhat et al., 1995; d'Anglemont de Tassigny et al., 2007a). After central NMDA injection, all periventricular hypothalamic nuclei showed c-Fos-positive staining, including regions with GnRH cell bodies, but the GnRH neurons themselves did not show staining. This lack of c-Fos induction in GnRH neuron after NMDA injection has been reported by others (Saitoh et al., 1991; Lee et al., 1993). The absence of c-Fos in GnRH neurons combined with robust LH release after central NMDA stimulation in mutant mice suggests an intermediary signaling pathway (Fig. $8 \mathrm{~B}$ ).

A multitude of brain cells are responsible for controlling $\mathrm{GnRH}$ release into the pituitary portal circulation (Herbison, 2006). We investigated the effect of central NMDA administration on two neuronal populations known to participate in $\mathrm{GnRH}$ neuron activation. Catecholamine- and NO-synthesizing neurons in the hypothalamus are both activated by NMDA in normal and kisspeptin signaling-deprived mice. Catecholamine derivates, such as norepinephrine (NE) and dopamine, modulate GnRH release (Negro-Vilar et al., 1979). The action of NMDA on cathecholaminergic neurons may therefore participate in the Kpindependent activation of $\mathrm{GnRH} / \mathrm{LH}$ release. However, recent findings have shown that NE suppresses GnRH neuron excitability in the adult mouse (Han and Herbison, 2008) and force a reanalysis of existing models explaining the effects of NE on gonadotropin secretion. Moreover, NMDA receptors have been demonstrated in the brainstem in which catecholamine neurons, which project to the hypothalamus, could play a role in mediating the NMDA effects on GnRH release (Urbanski et al., 1997). This population of nonhypothalamic neurons has not been investigated in the present study.
The gaseous neurotransmitter NO has also been suggested to mediate the effects of glutamate on GnRH neurons (Mahesh and Brann, 2005). Nitric oxide synthase-containing neurons surround GnRH cell bodies (Herbison et al., 1996) and coexpress NMDA receptor subunits in the rat (Bhat et al., 1995; d'Anglemont de Tassigny et al., 2007a). Moreover, glutamateinduced $\mathrm{GnRH}$ release can be blocked by a competitive inhibitor of NO or by NO scavenger molecules (Rettori et al., 1994). We show here that NMDA stimulates nNOS-containing neurons in Kiss 1 and Gpr54 mutant mice by the same extent as in wild-type animals. Thus, NO synthesis may also contribute to Kp-independent central action of NMDA on GnRH neurons. However, the sole presence of c-Fos in nNOS neurons after NMDA does not prove an effective synthesis of NO. Comparative studies assessing the levels of NO after NMDA stimulation in the different genotypes would reinforce our observations. Studies in the rat have shown that pretreatment with L-NAME $(N-\omega$-nitro-L-arginine methyl ester, a nitric oxide synthase antagonist) does not abrogate Kp10-induced LH release (Navarro et al., 2005). In addition, pretreatment with the NMDA receptor antagonist MK-801 [(+)-5-methyl-10,11-dihydro-5H-dibenzo [a,d] cyclohepten5,10-imine maleate] also failed to stop Kp10-induced LH release (Navarro et al., 2005). Additional studies are needed to fully understand the interrelationship between $\mathrm{NO}$ and kisspeptin in the regulation of $\mathrm{GnRH} / \mathrm{LH}$ release.

It has been recognized that neurons may require a strong stimulus to activate c-Fos expression (Dragunow and Faull, 1989), suggesting that NMDA may not sufficiently induce c-Fos expression to be detectable by immunocytochemistry despite cell body stimulation. Considering the high dose of intracerebroventricular NMDA used in our experiments and the large density of c-Fos-positive hypothalamic cells after NMDA injection, we as- 
sume that a strong stimulus was applied. However, NO can activate c-Fos expression within 30 min (Hemish et al., 2003).

We noted a higher $\mathrm{LH}$ response after central injection of NMDA or Kp in Kiss1-null mice than in wild-type mice. The reason for this is not known. A higher percentage of GnRH neurons with c-Fos in the MS/DBB subpopulation in Kiss1 mutants was correlated to the higher LH release in these mice. However, peripheral Kp10 also induced higher LH release in Kiss1-null mice. A larger pool of $\mathrm{GnRH}$ at nerve terminals, a hypersensitivity of the gonadotrophs to GnRH involving a higher density of $\mathrm{GnRH}$ receptors, or a higher $\mathrm{LH}$ content within gonadotrophs may account for the higher LH release in Kiss 1 mutants. These two later possibilities may be tested by priming the animals with $\mathrm{GnRH}$ before administering Kp or NMDA. A presynaptic high GnRH concentration in mutant mice has been observed in Gpr54-null hypothalamic explants (d'Anglemont de Tassigny et al., 2008).

The BBB restricts and regulates the flux of substrates between the circulation and the CNS. Therefore, peripheral Kp10 and NMDA may act only on brain regions outside of the BBB, such as the median eminence. The ability of Kp10 to cross the BBB remains to be proven. The uptake of glutamate from the blood circulation is limited by the BBB. Glutamate flux from plasma into brain is mediated by a high-affinity transport system at the $\mathrm{BBB}$, and restricted passage is also observed for several excitatory glutamate analogs (Smith, 2000). Although NMDA can disrupt the BBB permeability (Brace et al., 1997), whether NMDA itself crosses the BBB is an open question, but it is clear that the route of administration affects its penetration into the brain and thus its effect on the GnRH system.

In summary, this comparative study allowed discrimination between two modes of action of NMDA. A global hypothalamic $\mathrm{Kp}$-independent action revealed by central administration, and a region restricted $\mathrm{Kp}$-dependent action at the Arc revealed by peripheral administration (Fig. 8). NMDA stimulates Kiss1expressing neurons in the Arc to induce $\mathrm{LH}$ release. In more rostral hypothalamic regions, NMDA stimulates other brain cells, such as catecholamine- and NO-producing neurons that may mediate its action on the GnRH neurons. The present results extend our knowledge on the physiological role of $\mathrm{Kp} /$ GPR54 signaling and raise a new level of complexity in the GnRH network.

\section{References}

Beauvillain JC, Tramu G (1980) Immunocytochemical demonstration of LH-RH, somatostatin, and ACTH-like peptide in osmium-postfixed, resin-embedded median eminence. J Histochem Cytochem 28:10141017.

Bhat GK, Mahesh VB, Lamar CA, Ping L, Aguan K, Brann DW (1995) Histochemical localization of nitric oxide neurons in the hypothalamus: association with gonadotropin-releasing hormone neurons and co-localization with $\mathrm{N}$-methyl-D-aspartate receptors. Neuroendocrinology 62:187-197.

Bourguignon JP, Gerard A, Mathieu J, Simons J, Franchimont P (1989) Pulsatile release of gonadotropin-releasing hormone from hypothalamic explants is restrained by blockade of $N$-methyl-D,L-aspartate receptors. Endocrinology 125:1090-1096.

Bourguignon JP, Gérard A, Purnelle G, Czajkowski V, Yamanaka C, Lemaître M, Rigo JM, Moonen G, Franchimont P (1997) Duality of glutamatergic and GABAergic control of pulsatile GnRH secretion by rat hypothalamic explants. I. Effects of antisense oligodeoxynucleotides using explants including or excluding the preoptic area. J Neuroendocrinol 9:183-191.

Brace H, Latimer M, Winn P (1997) Neurotoxicity, blood-brain barrier breakdown, demyelination and remyelination associated with NMDAinduced lesions of the rat lateral hypothalamus. Brain Res Bull 43:447-455.
Cicero TJ, Meyer ER, Bell RD (1988) Characterization and possible opioid modulation of $\mathrm{N}$-methyl-D-aspartic acid induced increases in serum luteinizing hormone levels in the developing male rat. Life Sci 42:1725-1732.

Clarkson J, d'Anglemont de Tassigny X, Moreno AS, Colledge WH, Herbison AE (2008) Kisspeptin-GPR54 signaling is essential for preovulatory gonadotropin-releasing hormone neuron activation and the luteinizing hormone surge. J Neurosci 28:8691-8697.

Clarkson J, d'Anglemont de Tassigny X, Colledge WH, Caraty A, Herbison AE (2009) Distribution of kisspeptin neurones in the adult female mouse brain. J Neuroendocrinol 21:673-682.

Claypool LE, Kasuya E, Saitoh Y, Marzban F, Terasawa E (2000) N-methyl D,L-aspartate induces the release of luteinizing hormone-releasing hormone in the prepubertal and pubertal female rhesus monkey as measured by in vivo push-pull perfusion in the stalk-median eminence. Endocrinology 141:219-228.

d'Anglemont de Tassigny X, Campagne C, Dehouck B, Leroy D, Holstein GR, Beauvillain JC, Buée-Scherrer V, Prevot V (2007a) Coupling of neuronal nitric oxide synthase to NMDA receptors via postsynaptic density-95 depends on estrogen and contributes to the central control of adult female reproduction. J Neurosci 27:6103-6114.

d'Anglemont de Tassigny X, Fagg LA, Dixon JP, Day K, Leitch HG, Hendrick AG, Zahn D, Franceschini I, Caraty A, Carlton MB, Aparicio SA, Colledge WH (2007b) Hypogonadotropic hypogonadism in mice lacking a functional Kiss1 gene. Proc Natl Acad Sci U S A 104:10714-10719.

d'Anglemont de Tassigny X, Fagg LA, Carlton MB, Colledge WH (2008) Kisspeptin can stimulate gonadotropin-releasing hormone $(\mathrm{GnRH})$ release by a direct action at GnRH nerve terminals. Endocrinology 149:3926-3932.

Decourt C, Tillet Y, Caraty A, Franceschini I, Briant C (2008) Kisspeptin immunoreactive neurons in the equine hypothalamus Interactions with GnRH neuronal system. J Chem Neuroanat 36:131-137.

Dhillo WS, Chaudhri OB, Patterson M, Thompson EL, Murphy KG, Badman MK, McGowan BM, Amber V, Patel S, Ghatei MA, Bloom SR (2005) Kisspeptin-54 stimulates the hypothalamic-pituitary gonadal axis in human males. J Clin Endocrinol Metab 90:6609-6615.

Dragunow M, Faull R (1989) The use of c-fos as a metabolic marker in neuronal pathway tracing. J Neurosci Methods 29:261-265.

Dungan HM, Gottsch ML, Zeng H, Gragerov A, Bergmann JE, Vassilatis DK, Clifton DK, Steiner RA (2007) The role of kisspeptin-GPR54 signaling in the tonic regulation and surge release of gonadotropin-releasing hormone/luteinizing hormone. J Neurosci 27:12088-12095.

Franklin KBJ, Paxinos G (2001) The mouse brain in stereotaxic coordinates, Ed 2. San Diego: Academic.

Friedrich VL Jr, Holstein GR, Li X, Gow A, Kelley KA, Lazzarini RA (1993) Intracellular distribution of transgenic bacterial beta-galactosidase in central nervous system neurons and neuroglia. J Neurosci Res 36:88-98.

Funes S, Hedrick JA, Vassileva G, Markowitz L, Abbondanzo S, Golovko A, Yang S, Monsma FJ, Gustafson EL (2003) The KiSS-1 receptor GPR54 is essential for the development of the murine reproductive system. Biochem Biophys Res Commun 312:1357-1363.

Gottsch ML, Cunningham MJ, Smith JT, Popa SM, Acohido BV, Crowley WF, Seminara S, Clifton DK, Steiner RA (2004) A role for kisspeptins in the regulation of gonadotropin secretion in the mouse. Endocrinology 145:4073-4077.

Han SK, Herbison AE (2008) Norepinephrine suppresses gonadotropinreleasing hormone neuron excitability in the adult mouse. Endocrinology 149:1129-1135.

Han SK, Gottsch ML, Lee KJ, Popa SM, Smith JT, Jakawich SK, Clifton DK, Steiner RA, Herbison AE (2005) Activation of gonadotropin-releasing hormone neurons by kisspeptin as a neuroendocrine switch for the onset of puberty. J Neurosci 25:11349-11356.

Hemish J, Nakaya N, Mittal V, Enikolopov G (2003) Nitric oxide activates diverse signaling pathways to regulate gene expression. J Biol Chem 278:42321-42329.

Herbison AE (2006) Physiology of the GnRH neuronal network. In: Knobil and Neill's physiology of reproduction, Ed 3 (Neill JD, ed), pp 1415-1482. Boston: Elsevier.

Herbison AE, Simonian SX, Norris PJ, Emson PC (1996) Relationship of neuronal nitric oxide synthase immunoreactivity to GnRH neurons in the ovariectomized and intact female rat. J Neuroendocrinol 8:73-82.

Herbison AE, de Tassigny X, Doran J, Colledge WH (2010) Distribution 
and postnatal development of Gpr54 gene expression in mouse brain and gonadotropin-releasing hormone neurons. Endocrinology 151:312-321.

Horger BA, Nishimura MC, Armanini MP, Wang LC, Poulsen KT, Rosenblad C, Kirik D, Moffat B, Simmons L, Johnson E Jr, Milbrandt J, Rosenthal A, Bjorklund A, Vandlen RA, Hynes MA, Phillips HS (1998) Neurturin exerts potent actions on survival and function of midbrain dopaminergic neurons. J Neurosci 18:4929-4937.

Irwig MS, Fraley GS, Smith JT, Acohido BV, Popa SM, Cunningham MJ, Gottsch ML, Clifton DK, Steiner RA (2004) Kisspeptin activation of gonadotropin releasing hormone neurons and regulation of KiSS-1 mRNA in the male rat. Neuroendocrinology 80:264-272.

Kauffman AS, Park JH, McPhie-Lalmansingh AA, Gottsch ML, Bodo C, Hohmann JG, Pavlova MN, Rohde AD, Clifton DK, Steiner RA, Rissman EF (2007) The kisspeptin receptor GPR54 is required for sexual differentiation of the brain and behavior. J Neurosci 27:8826-8835.

Keen KL, Wegner FH, Bloom SR, Ghatei MA, Terasawa E (2008) An increase in kisspeptin-54 release occurs with the pubertal increase in luteinizing hormone-releasing hormone- 1 release in the stalk-median eminence of female rhesus monkeys in vivo. Endocrinology 149: 4151-4157.

Kotani M, Detheux M, Vandenbogaerde A, Communi D, Vanderwinden JM, Le Poul E, Brézillon S, Tyldesley R, Suarez-Huerta N, Vandeput F, Blanpain C, Schiffmann SN, Vassart G, Parmentier M (2001) The metastasis suppressor gene KiSS-1 encodes kisspeptins, the natural ligands of the orphan G protein-coupled receptor GPR54. J Biol Chem 276:34631-34636.

Lapatto R, Pallais JC, Zhang D, Chan YM, Mahan A, Cerrato F, Le WW, Hoffman GE, Seminara SB (2007) Kiss1-/- mice exhibit more variable hypogonadism than Gpr54-/- mice. Endocrinology 148:4927-4936.

Lee WS, Abbud R, Hoffman GE, Smith MS (1993) Effects of N-methyl-Daspartate receptor activation on cFos expression in luteinizing hormonereleasing hormone neurons in female rats. Endocrinology 133:2248-2254.

Mahesh VB, Brann DW (2005) Regulatory role of excitatory amino acids in reproduction. Endocrine 28:271-280.

Messager S, Chatzidaki EE, Ma D, Hendrick AG, Zahn D, Dixon J, Thresher RR, Malinge I, Lomet D, Carlton MB, Colledge WH, Caraty A, Aparicio SA (2005) Kisspeptin directly stimulates gonadotropin-releasing hormone release via G protein-coupled receptor 54. Proc Natl Acad Sci U S A 102:1761-1766.

Muir AI, Chamberlain L, Elshourbagy NA, Michalovich D, Moore DJ, Calamari A, Szekeres PG, Sarau HM, Chambers JK, Murdock P, Steplewski K, Shabon U, Miller JE, Middleton SE, Darker JG, Larminie CG, Wilson S, Bergsma DJ, Emson P, Faull R, Philpott KL, Harrison DC (2001) AXOR12, a novel human $G$ protein-coupled receptor, activated by the peptide KiSS-1. J Biol Chem 276:28969-28975.

Navarro VM, Castellano JM, Fernández-Fernández R, Barreiro ML, Roa J, Sanchez-Criado JE, Aguilar E, Dieguez C, Pinilla L, Tena-Sempere M (2004) Developmental and hormonally regulated messenger ribonucleic acid expression of KiSS-1 and its putative receptor, GPR54, in rat hypothalamus and potent luteinizing hormone-releasing activity of KiSS-1 peptide. Endocrinology 145:4565-4574.

Navarro VM, Castellano JM, Fernández-Fernández R, Tovar S, Roa J, Mayen A, Nogueiras R, Vazquez MJ, Barreiro ML, Magni P, Aguilar E, Dieguez C, Pinilla L, Tena-Sempere M (2005) Characterization of the potent luteinizing hormone-releasing activity of KiSS-1 peptide, the natural ligand of GPR54. Endocrinology 146:156-163.

Negro-Vilar A, Ojeda SR, McCann SM (1979) Catecholaminergic modulation of luteinizing hormone-releasing hormone release by median eminence terminals in vitro. Endocrinology 104:1749-1757.

Ohtaki T, Shintani Y, Honda S, Matsumoto H, Hori A, Kanehashi K, Terao Y, Kumano S, Takatsu Y, Masuda Y, Ishibashi Y, Watanabe T, Asada M, Yamada T, Suenaga M, Kitada C, Usuki S, Kurokawa T, Onda H, Nishimura
O, Fujino M (2001) Metastasis suppressor gene KiSS-1 encodes peptide ligand of a G-protein-coupled receptor. Nature 411:613-617.

Olney JW, Cicero TJ, Meyer ER, de Gubareff T (1976) Acute glutamateinduced elevations in serum testosterone and luteinizing hormone. Brain Res 112:420-424.

Ondo JG, Pass KA, Baldwin R (1976) The effects of neurally active amino acids on pituitary gonadotropin secretion. Neuroendocrinology 21: $79-87$.

Ottem EN, Godwin JG, Petersen SL (2002) Glutamatergic signaling through the $\mathrm{N}$-methyl-D-aspartate receptor directly activates medial subpopulations of luteinizing hormone-releasing hormone (LHRH) neurons, but does not appear to mediate the effects of estradiol on LHRH gene expression. Endocrinology 143:4837-4845.

Page AJ, O'Donnell TA, Cooper NJ, Young RL, Blackshaw LA (2009) Nitric oxide as an endogenous peripheral modulator of visceral sensory neuronal function. J Neurosci 29:7246-7255.

Parent AS, Matagne V, Bourguignon JP (2005) Control of puberty by excitatory amino acid neurotransmitters and its clinical implications. Endocrine 28:281-286.

Plant TM, Gay VL, Marshall GR, Arslan M (1989) Puberty in monkeys is triggered by chemical stimulation of the hypothalamus. Proc Natl Acad Sci U S A 86:2506-2510.

Ramaswamy S, Guerriero KA, Gibbs RB, Plant TM (2008) Structural interactions between kisspeptin and GnRH neurons in the mediobasal hypothalamus of the male rhesus monkey (Macaca mulatta) as revealed by double immunofluorescence and confocal microscopy. Endocrinology 149:4387-4395.

Rettori V, Kamat A, McCann SM (1994) Nitric oxide mediates the stimulation of luteinizing-hormone releasing hormone release induced by glutamic acid in vitro. Brain Res Bull 33:501-503.

Richard N, Galmiche G, Corvaisier S, Caraty A, Kottler ML (2008) KiSS-1 and GPR54 genes are co-expressed in rat gonadotrophs and differentially regulated in vivo by oestradiol and gonadotrophin-releasing hormone. J Neuroendocrinol 20:381-393.

Saitoh Y, Silverman AJ, Gibson MJ (1991) Norepinephrine neurons in mouse locus coeruleus express c-fos protein after $\mathrm{N}$-methyl-D,L-aspartic acid (NMDA) treatment: relation to LH release. Brain Res 561:11-19.

Selmanoff MK, Goldman BD, Ginsburg BE (1977) Developmental changes in serum luteinizing hormone, follicle stimulating hormone and androgen levels in males of two inbred mouse strains. Endocrinology 100: 122-127.

Seminara SB, Messager S, Chatzidaki EE, Thresher RR, Acierno JS Jr, Shagoury JK, Bo-Abbas Y, Kuohung W, Schwinof KM, Hendrick AG, Zahn D, Dixon J, Kaiser UB, Slaugenhaupt SA, Gusella JF, O’Rahilly S, Carlton MB, Crowley WF Jr, Aparicio SA, Colledge WH (2003) The GPR54 gene as a regulator of puberty. N Engl J Med 349:1614-1627.

Shahab M, Mastronardi C, Seminara SB, Crowley WF, Ojeda SR, Plant TM (2005) Increased hypothalamic GPR54 signaling: a potential mechanism for initiation of puberty in primates. Proc Natl Acad Sci U S A 102:2129-2134.

Smith QR (2000) Transport of glutamate and other amino acids at the blood-brain barrier. J Nutr 130:1016S-1022S.

Urbanski HF, Garyfallou VT, Kohama SG, Hess DL (1997) Alphaadrenergic receptor antagonism and $N$-methyl-D-aspartate (NMDA) induced luteinizing hormone release in female rhesus macaques. Brain Res 744:96-104.

Wintermantel TM, Campbell RE, Porteous R, Bock D, Gröne HJ, Todman MG, Korach KS, Greiner E, Pérez CA, Schütz G, Herbison AE (2006) Definition of estrogen receptor pathway critical for estrogen positive feedback to gonadotropin-releasing hormone neurons and fertility. Neuron 52:271-280. 